\title{
Analysis of expectations of parents of young school-age children towards school health education and health promotion activities in the teaching and upbringing environment, and health behaviours in the children's families
}

\author{
Analiza oczekiwań rodziców dzieci w wieku wczesnoszkolnym wobec \\ szkolnej edukacji zdrowotnej i działań promujących zdrowie w środowisku \\ nauczania i wychowania a zachowania zdrowotne w rodzinie ucznia
}

\author{
Justyna Chałdaś-Majdańska1 ${ }^{\oplus}$, Dragana Terzic-Markovic ${ }^{2 \oplus}$, Zvonko Dimoski $^{2 \oplus}$, \\ Beata Dobrowolska ${ }^{1 \oplus}$ \\ ${ }^{1}$ Department of Nursing Development, Medical University, Lublin, Poland \\ ${ }^{2}$ Academy for Applied Studies Belgrade (AASB), Department of Higher Medical School, Belgrade, Serbia
}

Chałdaś-Majdańska J. Analysis of expectations of parents of young school-age children towards school health education and health promotion activities in the teaching and upbringing environment, and health behaviours in the children's families. Med Og Nauk Zdr. 2020; 26(2): 155-163. doi: 10.26444/monz/120150

\section{Abstract}

Introduction. Health education aims to provide healthy or sick people with the knowledge and skills required for health-friendly behaviour. School plays a special role in the implementation of health education because health education is the fundamental right of every child.

Objective. The aim of the study was an analysis of the expectations of parents of young school-age children in relation to school health education and health promotion activities in the teaching and upbringing environment, and examining the relationship between these expectations and health behaviours of the family.

Materials and method. The diagnostic survey method was applied. Research was conducted with author's own questionnaire and the Health Behaviour Inventory (HBI) questionnaire by Juczyński. The study covered parents of young school-age children (6-9-years-old).

Results. Over half of the surveyed parents confirmed that the school implemented activities promoting health among its students. Almost $100 \%$ of parents expected that during talks on health promotion, they would raise the topics of: the principles of healthy eating, effects of using stimulants and addictions, regular visits to the doctor and dentist, and ways for coping with stress. The increase in the opinions of respondents about the implementation of active counselling in the field of nursing care was statistically related to the result in terms of proper eating habits, preventive behaviours and general assessment of health behaviours on the HBI scale. The more the respondents agreed with the statement that medical activities should not be carried out at school, the lower the result observed of health practices on the $\mathrm{HBI}$ scale.

Address for correspondence:Justyna Chałdaś-Majdańska, Department of Nursing Development, Medical University, Lublin, Poland

E-mail:justynachaldas@wp.pl

Received: 22.11.2019; accepted: 06.04.2020; first published: 13.05 .2020
Conclusions. The expectations of parents of young schoolage children regarding school medical care and healthy school activities are very high. The study demonstrated the existence of a relationship between parents' expectations of health promoting activities in the teaching and upbringing environment and health behaviours in the child's family.

\section{Key words}

parental expectations, young school-age children, school health education, health-promoting school activity, health behaviours

\section{Streszczenie}

Wstęp. Edukacja zdrowotna ma na celu zaopatrzenie osób zdrowych bądź chorych w wiedzę i umiejętności konieczne dla podejmowania zachowań korzystnych dla zdrowia. Szczególną rolę w realizacji edukacji zdrowotnej odgrywa szkoła, ponieważ edukacja w tym zakresie jest fundamentalnym prawem każdego dziecka.

Cel pracy. Analiza oczekiwań rodziców dzieci w wieku wczesnoszkolnym wobec szkolnej edukacji zdrowotnej i działań promujących zdrowie w środowisku nauczania i wychowania oraz zbadanie zależności między tymi oczekiwaniami a zachowaniami zdrowotnymi w rodzinie.

Materiał i metody. Zastosowano metodę sondażu diagnostycznego. Do celów badawczych wykorzystano kwestionariusz ankiety własnej oraz kwestionariusz IZZ Juczyńskiego. Badaniem zostali objęci rodzice uczniów dzieci w wieku wczesnoszkolnym (6-9 lat).

Wyniki. Ponad połowa badanych rodziców potwierdza, iż szkoła realizuje działania promujące zdrowie wśród uczniów. Blisko $100 \%$ rodziców oczekuje, aby podczas pogadanek z zakresu promocji zdrowia poruszyć tematykę zasad zdrowego żywienia skutków stosowania używek i nałogów, regularności wizyt u lekarza i stomatologa radzenia sobie ze stresem. 
Wzrost natężenia opinii ankietowanych na temat realizacji czynnego poradnictwa w zakresie opieki pielęgniarskiej ma statystyczny związek z wynikiem w zakresie prawidłowych nawyków żywieniowych, zachowań profilaktycznych oraz ogólnej oceny zachowań zdrowotnych w skali IZZ. Im bardziej badani zgadzali się ze stwierdzeniem, iż działania medyczne nie powinny być realizowane w szkole, tym silniejszy można było dostrzec spadek wyników w zakresie praktyk zdrowotnych w skali IZZ.

Wnioski. Oczekiwania rodziców dzieci w wieku wczesnoszkolnym wobec szkolnej opieki medycznej i prozdrowotnej aktywności szkoły są bardzo wysokie. Wykazano zależność między oczekiwaniami rodziców wobec działań promujących zdrowie w środowisku nauczania i wychowania a zachowaniami zdrowotnymi w rodzinie dziecka.

\section{Słowa kluczowe}

zachowania zdrowotne, oczekiwania rodziców, dzieci w wieku wczesnoszkolnym, szkolna edukacja zdrowotna, prozdrowotna aktywność szkoły

\section{INTRODUCTION}

The current core curriculum assigns the implementation of health education tasks to physical education teachers, which should take place as part of their subject in cooperation with he school nurse [1]. The task of the school in protecting and promoting the health of students and employees is to create the conditions required to implement preventive health care for the students [2]. The implementation of a health promotion programme in health education at school enables students to learn and understand the concepts of health, illness, self-care and the individual's impact on their own health [3]. What is particularly important in this context is the relationship between school and parents, as it may affect the effect of promoting student's health, i.e. reduce or completely eliminate the "data conflict", introducing the student into information chaos hindering the critical assessment of other sources of health information [4].

Becoming familiar with the correct attitudes towards health by children at a younger school age is important because they shape the style of conduct in adult life [5]. In the case of young people, the long-term perspective of health disorders is not a sufficient argument to change their antihealth behaviours. In the process of health education, the level of knowledge about health should be increased, taking into account its socio-economic determinants, as well as knowledge and skills related to a healthy lifestyle in various living conditions, taking into account self-assessment, self-efficacy and social support. It is also important to develop awareness of the relationship between population health and its socio-economic development. To sum up, an effective impact on human health requires not only raising the individuals' health knowledge and shaping life skills for health, but also interventional environmental actions aimed at intensifying the impact of factors supporting health, and limiting or eliminating those that are harmful to health [6].

Health education in preschool and early school is characterized by the successive "empowerment" of the child. Its participation in the quest for his or her own health increases, and awareness and sense of responsibility develop. The guidelines listed below are well-worth following when promoting health among children:

- capture the student's emotional engagement for health and hygiene;

- adapt the forms of individual and group work to the nature of classmate relations;

- satisfy children's curiosity regarding the development of the body, its functions and the necessary hygiene pro- cedures, adapting the explanations to their perceptive capabilities;

- replace actions undertaken by children that may be dangerous for them, with others equally attractive, but do not threatening their lives and health;

- demonstrate to the children the benefits of taking care of health in a matter-of-fact and not just verbal way;

- above all, present good role models while introducing negative examples only to oppose and emphasize positive examples;

- ensure the attractiveness of the contents taught [6].

\section{OBJECTIVE}

The aim of the study was to analyse the expectations of parents of young school-age children in relation to school health education and health promotion activities in the teaching and upbringing environment, and to examine the relationship between these expectations and health behaviours of the family.

\section{MATERIALSAND METHOD}

The diagnostic survey method was applied with 2 separate tools: authors' own questionnaire created on the basis of literature analysis and Juczyński's Inventory of Health Behaviours (HBI) purchased from the Psychological Test Laboratory of the Polish Psychological Association [7]. The author's questionnaire consisted of 2 parts: sociodemographic questions and 16 questions about parents' expectations of health promoting activities in the school environment of their children. Answers to questions about parents' opinions on their expectations for health promotion activities in the teaching and upbringing environment were based on a 5-point Likert scale with a neutral mid-position option (ranging from 'definitely yes' to 'definitely no').

HBI contains 24 statements describing various types of health-related behaviours (eating habits, preventive behaviours, positive mental attitudes, health practices). And thus correct eating habits taking into account the type of food consumed; preventive behaviour concerning compliance with health recommendations and obtaining information on health and illness; positive mental attitudes, including psychological factors, such as avoiding excessive emotions, stress and tension, or depressing situations; health practices relating to daily sleep and recreation, and physical activity habits [7].

The study was conducted in 2017 in primary schools in the Mazowieckie Province in eastern-central Poland. Consent 
of the school directors was obtained for the research and the research protocol positively assessed by the Bioethics Committee at the Medical University of Lublin in eastern Poland (Consent No. KE-0254/8/2017).

The study covered parents of young school-age children (6-9-years-old). Prior to the start of the study, respondents were assured that the study was anonymous and informed that participation was entirely voluntary and that they could withdraw at any time. Each of the parents received and signed an informed consent form to participate in the study.

The collected research material was processed with use of the IBM SPSS Statistics software suite. Spearman's rank correlation coefficient was applied to determine the relationship between variables (taking into account the scale of measuring variables). Significance level $p<0.05$ was adopted.

Study group characteristics. Questionnaires were distributed to 150 respondents, 138 of which were returned correctly completed (return level of $92 \%) .87 \%(n=120)$ of the respondents were mothers of children at early school age and $13 \%(n=18)$ the fathers. The average age of the respondents was 35.39 years. Over half of the respondents came from rural areas $(n=91 ; 65.9 \%)$; the rest came from a city $(n=47 ; 34.1 \%)$. Most parents had secondary education $(n=51 ; 37 \%)$, followed by higher education $(n=41 ; 29.7 \%)$, vocational education ( $n$ $=36 ; 26.1 \%)$ and primary education $(n=10 ; 7.2 \%)$. Over half of the respondents $(n=78 ; 56.5 \%)$ were of the opinion that they have good material conditions, while $16.7 \%(n=23)$ of respondents assessed them as very good. Three people failed to answer this question. Almost all respondents $(n=130$; 94.2\%) presented the full condition of the family. Most of the parents surveyed $(n=106 ; 76.8 \%)$ had one child in the age range $6-9$ years, $21 \%(n=29)-2$ children of this age and $2.2 \%(n=3)-3$ children.

\section{RESULTS}

The mean HBI score of the study group was 84.69 ( $\mathrm{SD}=11.42$ ). The highest result was obtained on the Positive Mental Attitude scale, with a mean score of $3.67(\mathrm{SD}=0.56)$. The respondents presented slightly lower results in the area of Prophylactic Behaviours, with $3.58(\mathrm{SD}=0.65)$ and Correct Eating Habits, with 3.45 ( $\mathrm{SD}=0.61)$. The lowest rated were health practices, with a score of $3.41(\mathrm{SD}=0.56)$. According to current standards, low results were obtained by $24.6 \%$ of respondents, average $43.5 \%$, while high results were recorded by $31.9 \%$ of respondents.

Over half of the respondents stated that the school fulfills the task of implementing health promotion activities among students $(n=29 ; 21 \%$ "definitely yes" and $n=50$; $36.2 \%$ "rather yes"). Nearly $1 / 3$ of respondents $(n=39$; $28.3 \%$ ) were characterized by their lack of knowledge in the implementation of health promotion activities at school facilities. Other parents $(\mathrm{n}=18 ; 13 \%$ "rather not" and $=2$; $1.4 \%$ "definitely not") denied the implementation of such activities. In the respondents' opinions, the health promotion measures implemented in schools included: carrying out health evaluations $(n=38 ; 48.1 \%$ "definitely yes" and $n=28$; $35.4 \%$ "rather yes"); organizing art competitions on health $(\mathrm{n}=28 ; 35.4 \%$ "definitely yes" and $\mathrm{n}=32 ; 40.5 \%$ "rather yes"); nurse's cooperation with physical education teachers $(n=16$;
20.3\% “definitely yes" and n=26; 32.9\% "rather yes") (Tab. 1).

Parents were also asked about known health programmes implemented in many schools, such as the programme of the Minister of National Education, entitled "Mum, Dad, I prefer water." In the opinion of the majority of parents surveyed ( $n=14 ; 17.7 \%$ "definitely yes" and $n=29 ; 36.7 \%$ "rather yes"), this programme is implemented at the school, $36.7 \%(n=29)$ of respondents did not have knowledge on the subject; and $8.9 \%(n=7)$ of the parents thought that the school did not take part in this programme.

Parents were subsequently asked about the programme implemented by the Agricultural Market Agency "Fruit and vegetables at school". Over $90 \%$ of respondents ( $n=60 ; 75.9 \%)$ "definitely yes" and n=14 (17.7\%) "rather yes" and believed that the school participated in the programme. The last health programme asked about was the government support programme "Safe+" in 2015-2018, where 50\% of parents ( $n=14$; $17.7 \%$ ) stated "definitely yes" and $n=27 ; 34.2 \%$ "rather yes " that the school implemented it among the children (Tab. 1)

Parents' expectations were also investigated regarding the implementation of medical activities in the field of prevention and pre-medical assistance at school. In the opinion of $14.2 \%$ $(\mathrm{n}=8 ; 5.8 \%)$ "definitely yes" and "rather yes" $(13 ; 9.4 \%)$ of respondents that such activities should not be conducted at school. Over $80 \%$ of respondents paid attention to dental care, including checking the child's oral health and dental treatment, ( $\mathrm{n}=76$ (55.1\%) "definitely yes" and "rather yes" - 40 (29.0\%). 1/5 parents $-\mathrm{n}=25$ (8.1\%) "rather not" and "definitely not" $-\mathrm{n}=4(2.9 \%)$ opposed vaccination in cooperation with a paediatrician at school (Tab. 1)

Most of the parents who expressed their opinion on talks about health promotion at school denied the claim that "talks about health and care should not be conducted at school", $\mathrm{n}=28$ (20.3\%) "rather not" and n=86 (62.3\%) "definitely not"). As expected, they raised primarily the following issues: the principles of healthy eating - n=80 (58.0\%) "definitely yes", and "rather yes" in 55 (39.9\%); effects of using stimulants and addictions $-\mathrm{n}=104$; - (75.4\%) "definitely yes" and $\mathrm{n}=31$ (22.5\%) "rather yes"); regular visits to the doctor and dentist, $\mathrm{n}=69$ (50.0\%) "definitely yes", and n=65 (47.1\%) "rather yes"); ways of coping with stress $-\mathrm{n}=70(50.7 \%)$ "definitely yes", and $\mathrm{n}=63(45.7 \%)$ "rather yes"); safety rules in various situations and environments $-\mathrm{n}=86(62.3 \%)$ "definitely yes", and $\mathrm{n}=47$ (34.1\%) "rather yes" (Tab. 2)

The study group expressed an opinion on school display cases: L? of parents $-\mathrm{n}=7$ (5.1\%) "definitely yes" and $n=28$ (20.3\%) "rather yes" were of the opinion that school cases were not read by the children $-\mathrm{n}=46(33.3 \%)$ of respondents lacked knowledge on this topic. In the opinion of $97.1 \%$ of the surveyed parents, school display cases should present various aspects of the subject of health, communicated in a clear and understandable way - $\mathrm{n}=82$ (59.4\%) "definitely yes", and $\mathrm{n}=52$ (37.7\%) "rather yes". In the opinion of $95 \%$ of respondents, school display cases should take into account the issues of: health promotion $-\mathrm{n}=48$ (34.8\%) "definitely yes", and $\mathrm{n}=85$ (61.6\%) "rather yes", and the effects of using stimulants and addictions $-\mathrm{n}=83$ (60.1\%) "definitely yes", and $n=50$ (36.2\%) "rather yes". The lowest numbers of parents expected contents such as the impact of the physical environment and genetic factors on health $-\mathrm{n}=27$ (19.6\%) "definitely yes", and $\mathrm{n}=71$ (51.4\%) "rather yes", and the availability of medical services and their quality - $\mathrm{n}=28$ (20.3\%) "definitely yes", and $\mathrm{n}=71$ (51.4\%) "rather yes". (Tab. 2). 
Table 1. Parents' opinion on the implementation of activities promoting health at school and their expectations in this area

\begin{tabular}{|c|c|c|c|c|c|c|}
\hline \multicolumn{7}{|l|}{ Parents' opinion on the implementation of actions promoting health at school } \\
\hline & & Def. yes & Rather yes & I don't know & Rather not & Def. not \\
\hline There are educational classes and talks on health issues during the lessons & $\mathrm{n}$ & 22 & 34 & 18 & 4 & 1 \\
\hline \multirow{2}{*}{ The school nurse cooperates with physical education teachers } & $\mathrm{n}$ & 16 & 26 & 34 & 3 & 0 \\
\hline & $\%$ & 20.3 & 32.9 & 43.0 & 3.8 & 0.0 \\
\hline There are competitions organized, related to health care & $\%$ & 35.4 & 40.5 & 15.2 & 8.9 & 0.0 \\
\hline \multirow{2}{*}{ An information display cabinet with health issues is on display } & $\mathrm{n}$ & 28 & 28 & 19 & 4 & 0 \\
\hline & $\%$ & 35.4 & 35.4 & 24.1 & 5.1 & 0.0 \\
\hline \multirow{2}{*}{ Health evaluations are carried out } & $\mathrm{n}$ & 38 & 28 & 5 & 6 & 2 \\
\hline & $\%$ & 48.1 & 35.4 & 6.3 & 7.6 & 2.5 \\
\hline \multirow{2}{*}{ There are lectures and talks for parents } & $\mathrm{n}$ & 20 & 23 & 19 & 14 & 3 \\
\hline & $\%$ & 25.3 & 29.1 & 24.1 & 17.7 & 3.8 \\
\hline \multirow{2}{*}{ There is visible cooperation with the local community in health promotion activities } & $\mathrm{n}$ & 15 & 28 & 25 & 10 & 1 \\
\hline & $\%$ & 19.0 & 35.4 & 31.6 & 12.7 & 1.3 \\
\hline \multirow{2}{*}{$\begin{array}{l}\text { The school promotes the "Mum, Dad, I prefer water" program of the Minister of } \\
\text { National Education }\end{array}$} & $\mathrm{n}$ & 14 & 29 & 29 & 7 & 0.0 \\
\hline & $\%$ & 17.7 & 36.7 & 36.7 & 8.9 & 0 \\
\hline \multirow{2}{*}{$\begin{array}{l}\text { The school uses the program „School Fruits and Vegetables" implemented by the } \\
\text { Agricultural Market Agency }\end{array}$} & $\mathrm{n}$ & 60 & 14 & 5 & 0.0 & 0.0 \\
\hline & $\%$ & 75.9 & 17.7 & 6.3 & 0 & 0 \\
\hline \multirow{2}{*}{ The school uses the "Safe +" Government support program in 2015-2018 } & $\mathrm{n}$ & 14 & 27 & 34 & 3 & 1 \\
\hline & $\%$ & 17.7 & 34.2 & 43.0 & 3.8 & 1.3 \\
\hline \multicolumn{7}{|c|}{ Parents' expectations towards the implementation of preventive and pre-medical help activities at school } \\
\hline \multirow{2}{*}{ Dental care (checking the health of the child ss oral cavity, dental treatment at school) } & $\mathrm{n}$ & 76 & 40 & 13 & 6 & 3 \\
\hline & $\%$ & 55.1 & 29.0 & 9.4 & 4.3 & 2.2 \\
\hline Vaccinations in cooperation with a pediatrician at the school & $\%$ & 28.3 & 33.3 & 17.4 & 18.1 & 2.9 \\
\hline \multirow{2}{*}{ Medical activities should not be carried out at school } & $\mathrm{n}$ & 8 & 13 & 18 & 40 & 59 \\
\hline & $\%$ & 5.8 & 9.4 & 13.0 & 29.0 & 42.8 \\
\hline
\end{tabular}

The respondents' position on the ban on selling unhealthy food in school shops was also examined. Over half of the parents approved of the ban $-\mathrm{n}=47$ (34.1\%)" definitely agree", $\mathrm{n}=44(31.9 \%)$ "rather agree". However, $1 / 3$ of respondents - $n=43(31.2 \%)$ had no opinion on the topic. Nearly $3 \%$ of respondents were opposed to the ban $-\mathrm{n}=3(2.2 \%)$ "I rather disagree", and n=1 (0.7\%) "strongly disagree".

The respondents expressed their opinion on lunches served in the school canteen. According to $76.1 \%$ of parents, their children liked to eat lunch at school - n=35 (25.4\%) "definitely yes", and $n=70(50.7 \%)$ "rather yes". Some respondents $-\mathrm{n}=20$ (14.5\%) did not know the child's opinion on this topic, while others $-\mathrm{n}=2$ (1.4\%) "definitely not", and n=11 (8.0\%) "rather not", indicated that their children did not like their meals. In the opinion of $61.6 \%$ of respondents, the school lunches were rather unpalatable for children - n=53 (38.5\%) "definitely yes", and n=32 (23.1\%) "rather yes". Some respondents $-\mathrm{n}=32$ (23.1\%) also noted poorly seasoned and unsalted dishes. Parents also complained about the lack of two-course lunches and beverages served with them and too small portions $\mathrm{n}=11(7.7 \%)$ (Tab. 3).

Then the parents expressed their preferences for lunches in the school canteen. Most parents $-\mathrm{n}=113((81.9 \%)$, enrolled their children for school lunches. All respondents expected the vegetables and fruit to be included in the meals. Almost
$100 \%$ of respondents expressed an opinion on the compliance of school lunches with the principles of rational nutrition. Almost $1 / 3$ of respondents demand two-course lunches $\mathrm{n}=20$ (14.5\%) "definitely yes", and n= $17(12.3 \%)$ "rather yes", larger portions $-\mathrm{n}=14$ (10.1\%) “definitely yes", $\mathrm{n}=22(15.9 \%)$ "rather yes", and a sweet dessert with the meal - $\mathrm{n}=20(14.5 \%)$ "definitely yes", and n=26 (18.8\%) "rather yes".

Parents' knowledge of their children's participation in physical education classes was examined. In the opinion of $94.9 \%$ of respondents, their children take part in all physical education classes - n=70 (50.7\%) "definitely yes", and $n=61(44.2 \%)$ "rather yes". Lack of knowledge on this subject was reported by $n=5(3.6 \%)$ of respondents. According to 2 parents $(1.5 \%)$, their children did not participate in these activities

A higher parental agreement score on the performance of health education at school correlated with an increase in the results of the HBI scale in health practices. On the other hand, the greater the parents' agreement with the opinion that vaccination should be carried out in cooperation with a paediatrician at the school, the higher the result in their overall assessment of health behaviours on the HBI scale.

The increase in the opinions of respondents about the implementation of active counselling in the field of nursing care was statistically related to the result in terms of proper 
Table 2. Parents' expectations regarding the subject of talks on health promotion and information contained in school cabinets regarding health promotion activities

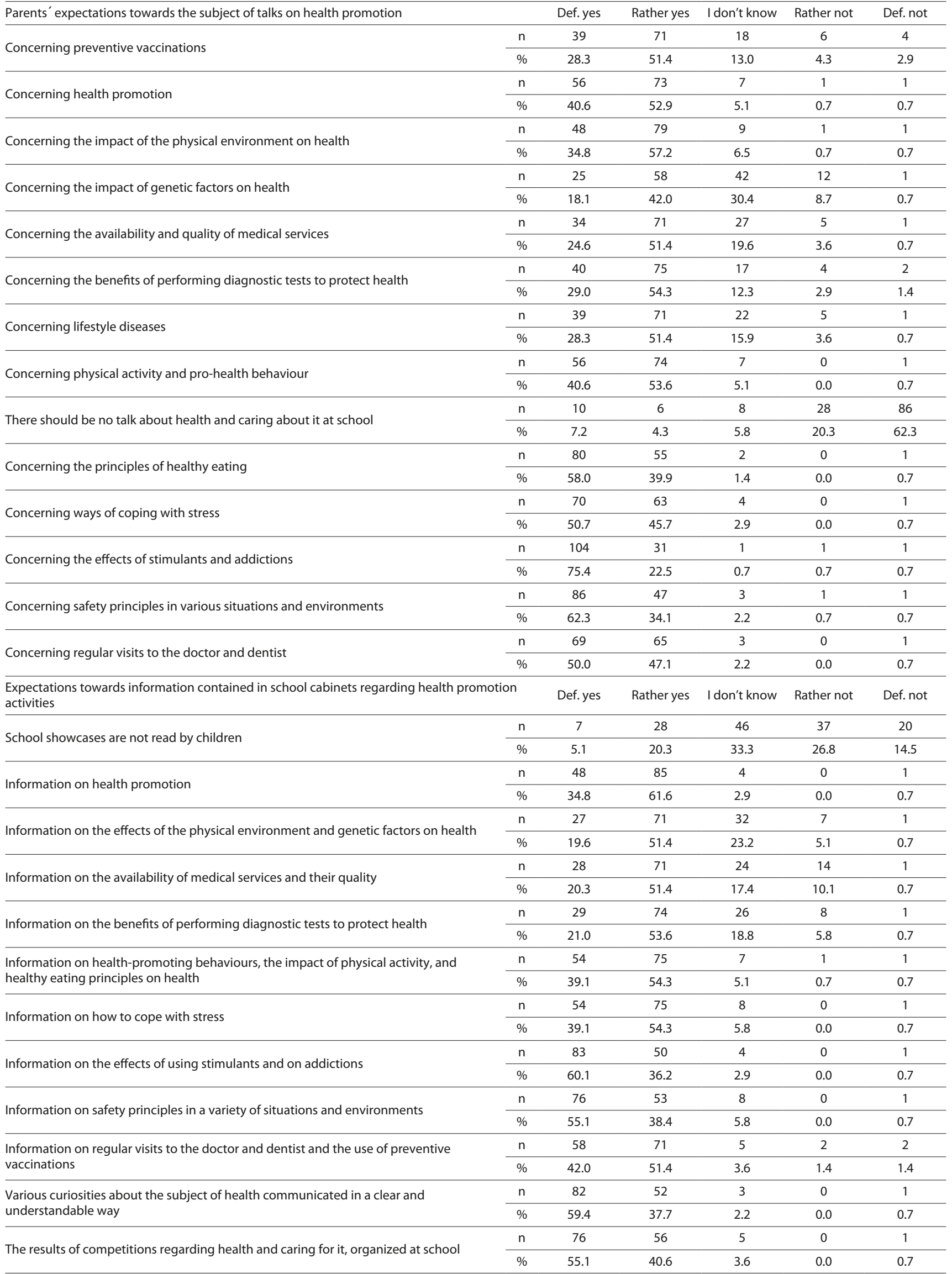


Table 3. Parents' opinion on children's preferences for school lunches

\begin{tabular}{|c|c|c|c|c|c|c|}
\hline & & Def. yes & Rather yes & I don't know & Rather not & Def. not \\
\hline \multirow{2}{*}{ Because children donst like school lunches } & $\mathrm{n}$ & 53 & 32 & 0 & 42 & 11 \\
\hline & $\%$ & 38.5 & 23.1 & 0.0 & 30.8 & 7.7 \\
\hline \multirow{2}{*}{ Because meals are unhealthy } & $\mathrm{n}$ & 0 & 0 & 21 & 85 & 32 \\
\hline & $\%$ & 0.0 & 0.0 & 15.4 & 61.5 & 23.1 \\
\hline \multirow{2}{*}{ Because the lunch portions are too small } & $\mathrm{n}$ & 11 & 0 & 21 & 74 & 32 \\
\hline & $\%$ & 7.7 & 0.0 & 15.4 & 53.8 & 23.1 \\
\hline \multirow{2}{*}{ Because the dishes repeat (no variety) } & $\mathrm{n}$ & 11 & 11 & 11 & 74 & 32 \\
\hline & $\%$ & 7.7 & 7.7 & 7.7 & 53.8 & 23.1 \\
\hline \multirow{2}{*}{ Because the dishes are oversalted } & $\mathrm{n}$ & 0 & 0 & 21 & 74 & 42 \\
\hline & $\%$ & 0.0 & 0.0 & 15.4 & 53.8 & 30.8 \\
\hline \multirow{2}{*}{ Because the dishes are not salted enough } & $\mathrm{n}$ & 0 & 32 & 21 & 53 & 32 \\
\hline & $\%$ & 0.0 & 23.1 & 15.4 & 38.5 & 23.1 \\
\hline \multirow{2}{*}{ Because the dishes are badly seasoned } & $\mathrm{n}$ & 11 & 21 & 32 & 42 & 32 \\
\hline & $\%$ & 7.7 & 15.4 & 23.1 & 30.8 & 23.1 \\
\hline \multirow{2}{*}{ Because some dishes are not sweet } & $\mathrm{n}$ & 0 & 21 & 32 & 64 & 21 \\
\hline & $\%$ & 0.0 & 15.4 & 23.1 & 46.2 & 15.4 \\
\hline \multirow{2}{*}{ Because lunches are not two-course } & $\mathrm{n}$ & 11 & 0 & 42 & 64 & 21 \\
\hline & $\%$ & 7.7 & 0.0 & 30.8 & 46.2 & 15.4 \\
\hline \multirow{2}{*}{ Because the child does not receive a beverage with a meal } & $n$ & 11 & 0 & 21 & 74 & 32 \\
\hline & $\%$ & 7.7 & 0.0 & 15.4 & 53.8 & 23.1 \\
\hline \multirow{2}{*}{ Because the child does not receive a sweet dessert with a meal } & $\mathrm{n}$ & 0 & 0 & 42 & 85 & 11 \\
\hline & $\%$ & 0.0 & 0.0 & 30.8 & 61.5 & 7.7 \\
\hline \multirow{2}{*}{ Other } & $\mathrm{n}$ & 3 & 0 & 0 & 0 & 0 \\
\hline & $\%$ & 100.0 & 0.0 & 0.0 & 0.0 & 0.0 \\
\hline
\end{tabular}

eating habits, preventive behaviours and general assessment of health behaviours on the HBI scale. The more the respondents agreed with the statement that medical activities should not be carried out at school, the lower the results observed of health practices on the HBI scale. Along with the increase in expectations about performing visual acuity tests and colour vision, the results in the HBI scale in terms of normal eating habits increased. The greater the acceptance of parents regarding the conducting of head lice prevention at school was associated with a higher result in the field of preventive behaviours (Tab. 4).

\section{DISCUSSION}

Analysis of the subject literature returned no research reports on parents' expectations of school health education. Researchers mainly focused on issues related to health education in schools, health promotion and health problems among students $[1,4,5,8,9,10,11]$. In the current study, the aspect covering parents' expectations of school health education is relatively new and therefore cannot be compared with other research results.

The presented study demonstrates that, in the opinion of more than half of the parents surveyed, the school implemented activities promoting health among its students. The results of research by Charzyńska-Gula et al. present the students' opinion on the implementation of classes on health principles, in which $22.28 \%$ stated that such classes are conducted [9].
In own research, more than half of the respondents expressed approval for vaccinations in cooperation with a paediatrician at school, although Pachla points out that since 2007 they have not been carried out at schools [12].

The results obtained in the presented study indicate that more than a half of the parents expressed their approval of the ban on selling unhealthy food in school shops, with a further $1 / 3$ of respondents having no opinion on this topic. As indicated by research by Kardas et al., before implementing the changes, most shops mostly had sweets, confectionery, sugar sweetened carbonated drinks and salty snacks on offer. A disturbing phenomenon at the time was the inability to buy vegetables and natural dairy products [13]. Furthermore, studies by Wolnicka et al. indicate that $80.5 \%$ of school heads declared that they introduced various types of restrictions in the shop assortment [14].

Bednarek et al. studied the health behaviours of younger school age children. Nearly half of the girls and about $40 \%$ of boys are of the opinion that their parents provide the most information on health-related behaviours [5]. It is therefore important for parents to demonstrate the desired behaviour. Based on the results of the current study, the average score of parents' health behaviour was 84.69 , with the parents scoring highest in the Positive Mental Attitude. 31.9\% of respondents demonstrated high scores in terms of health behaviours.

$94.9 \%$ of the surveyed parents shared the opinion that their children participated in every physical education class. A study by Grzywacz revealed that only $62 \%$ of children take active part in these classes, and 66\% were not made aware by parents and school guardians of the beneficial effects of 
Justyna Chałdaś-Majdańska, Dragana Terzic-Markovic, Zvonko Dimoski, Beata Dobrowolska. Analysis of expectations of parents of young school-age children...

Table 4. The relationship between parents 'expectations of health promoting activities at school and the child's parents' health behavior

Expectations of parents towards prevention and pre-medical assistance activities implemented at school

Health evaluations (measuring weight, height, blood pressure, etc.)

Performing and interpreting screening tests and managing screening procedures, as well as nursing care for students covered by these procedures

Dental care (checking the health of the child's oral cavity, dental treatment at school)

Conducting fluoride prophylaxis - supervised tooth brushing

Vaccinations in cooperation with a pediatrician at the school

Providing pre-medical assistance in case of sudden illnesses, injuries and poisonings

Advising the schoolss headmaster on the conditions of student safety, organization of meals and sanitary conditions at school

Participation in the planning, implementation and evaluation of the school health education program and taking other actions in the field of health promotion

Active counseling in the field of nursing care

Medical activities should not be carried out at schoo

Performing visual acuity and colour vision tests

Assessment of childrens> development based on percentile grids of height and body mass

Assessment of the child`s body posture

Conducting anti lice prophylaxis

Parents' expectations towards the subject of talks on health promotion

Concerning preventive vaccinations

Concerning health promotion

Concerning the impact of the physical environment on health

Concerning the impact of genetic factors on health

Concerning the availability and quality of medical services

Concerning the benefits of performing diagnostic tests to protect health

\section{Concerning lifestyle diseases}

Concerning physical activity and pro-health behaviour

There should be no talk about health and caring about it at school

There should be no talk about health and caring about it at school

Concerning the principles of healthy eating

Concerning ways of coping with stress

Concerning the effects of stimulants and addictions

\begin{tabular}{|c|c|c|c|c|c|}
\hline & CEH & PB & PMA & HP & IZZ \\
\hline rho & 0.137 & 0.110 & 0.083 & 0.176 & 0.150 \\
\hline$p$ & 0.108 & 0.199 & .331 & 0.039 & 0.079 \\
\hline rho & -0.073 & -0.034 & -0.046 & .041 & -0.043 \\
\hline$p$ & 0.394 & 0.696 & 589 & 1.630 & . .620 \\
\hline rho & -0.107 & 0.002 & -0.129 & 0.071 & -0.064 \\
\hline$p$ & 0.210 & 0.986 & 0.133 & 0.406 & 0.454 \\
\hline rho & -0.007 & 0.064 & -0.043 & -0.007 & -0.005 \\
\hline$p$ & 0.933 & 0.458 & 0.615 & 0.934 & 0.956 \\
\hline rho & 0.131 & 0.158 & 0.148 & 0.104 & 0.177 \\
\hline$p$ & 0.126 & 0.063 & 0.083 & 0.227 & 0.037 \\
\hline rho & 0.162 & 0.140 & 0.065 & 0.109 & 0.135 \\
\hline$p$ & 0.058 & 0.103 & 0.452 & 0.204 & 0.114 \\
\hline rho & 0.116 & 0.168 & 0.121 & 0.009 & 0.145 \\
\hline$p$ & 0.174 & 9 & & 0.917 & 0.090 \\
\hline rho & 0.117 & 0.137 & 0.118 & 0.012 & 0.127 \\
\hline$p$ & 0.172 & 0.108 & 0.168 & 0.893 & 0.137 \\
\hline rho & 0.207 & 0.178 & 0.139 & 0.021 & 0.167 \\
\hline$p$ & 0.015 & 0.036 & 0.104 & 0.804 & 0.050 \\
\hline rho & -0.073 & -0.011 & $-0,166$ & $-0,225$ & -0.122 \\
\hline$p$ & 0.396 & 0.899 & 0.051 & 0.008 & 0.154 \\
\hline rho & 0.172 & 0.136 & 0.083 & 0.096 & 0.141 \\
\hline$p$ & 0.044 & 0.112 & 0.333 & 0.262 & 0.100 \\
\hline rho & 0.075 & 0.059 & 0.055 & 0.137 & 0.080 \\
\hline$p$ & 0.380 & 0.495 & 0.524 & 0.110 & 0.350 \\
\hline rho & 0.014 & 0.053 & 0.065 & 0.061 & 0.049 \\
\hline$p$ & 0.867 & 0.540 & 0.446 & 0.474 & 0.566 \\
\hline rho & 0.083 & 0.232 & 0.164 & 0.040 & 0.159 \\
\hline$p$ & 0.333 & 0.006 & 0.055 & 0.639 & 0.063 \\
\hline & CEH & PB & PMA & HP & IZZ \\
\hline rho & -0.032 & 0.018 & 0.023 & 0.071 & 0.033 \\
\hline$p$ & 0.709 & 0.838 & 0.788 & 0.406 & 0.701 \\
\hline rho & 0.037 & -0.069 & -0.009 & -0.056 & -0.028 \\
\hline$p$ & 0.664 & 0.424 & 0.915 & 0.512 & 0.748 \\
\hline rho & 0.156 & 0.042 & 0.003 & -0.101 & 0.041 \\
\hline$p$ & 0.067 & 0.626 & 0.971 & 0.236 & 0.635 \\
\hline rho & 0.039 & 0.064 & 0.006 & 0.016 & 0.041 \\
\hline$p$ & 0.651 & 0.457 & 0.944 & 0.850 & 0.630 \\
\hline rho & 0.110 & 0.096 & 0.027 & -0.038 & 0.078 \\
\hline$p$ & 0.198 & 0.262 & 0.758 & 0.658 & 0.360 \\
\hline rho & 0.088 & 0.156 & 0.060 & -0.009 & 0.102 \\
\hline$p$ & 0.305 & 0.067 & 0.401 & נוס. & 0.232 \\
\hline rho & 0.294 & 0.174 & 0.142 & -0.022 & 0.186 \\
\hline$p$ & 0.000 & 0.041 & 0.097 & 0.001 & 0.029 \\
\hline rho & 0.208 & 0.109 & 0.063 & 0.054 & 0.139 \\
\hline$p$ & 0.014 & 0.204 & 0.464 & 0.531 & 0.104 \\
\hline rho & 0.061 & 0.062 & -0.101 & -0.053 & 0.011 \\
\hline$p$ & 0.479 & 0.470 & 0.236 & 0.536 & 0.899 \\
\hline rho & 0.009 & -0.040 & -0.051 & -0.112 & -0.050 \\
\hline$p$ & 0.914 & 0.638 & 0.555 & 0.190 & 0.562 \\
\hline rho & 0.019 & -0.063 & -0.075 & -0.020 & -0.028 \\
\hline$p$ & 0.823 & 0.460 & 0.384 & 0.814 & 0.744 \\
\hline rho & 0.028 & 0.077 & -0.006 & 0.025 & 0.049 \\
\hline & 0.746 & 0.370 & 0.946 & 0.768 & 0.567 \\
\hline
\end{tabular}


Table 4. The relationship between parents 'expectations of health promoting activities at school and the child's parents' health behavior (continuation)

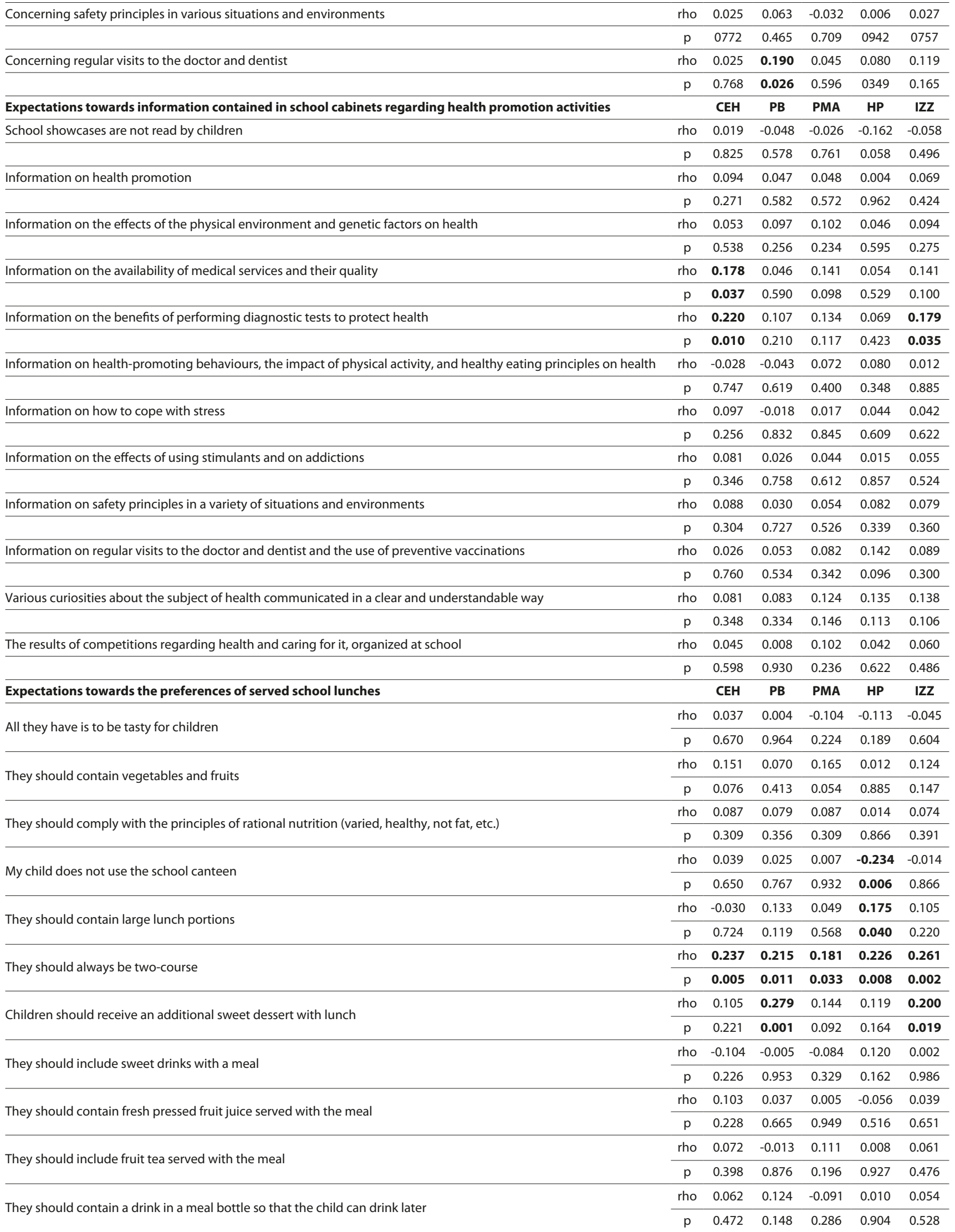

Key: CEH - Correct Eating Habits; PB - Preventive Behavior, PMA - Positive Mental Attitude; HP - Health Practices; IZZ - overall result 
physical recreation on the body [11]. However, own research shows that over $95 \%$ of parents expect issues regarding the impact of physical activity and healthy rational nutrition on the human health to be discussed at school.

Foster et al. demonstrated that mentoring on the part of parents has a significant impact on the treatment and prevention of childhood obesity [10]. Foreign authors, in addition to research on the subject of health education in schools and health promotion, have undertaken the introduction of innovative intervention programmes to improve students' health habits. The research by Minossi et al. also presents an educational programme for children and their families to change health habits among children struggling with health-related issues, including obesity. The study group participated in an 11 weeks programme of group education in nutrition and the importance of physical activity, provision of recommendations and brochures with written guidelines; organization of culinary workshops; games and homework, motivating parents by sending them texts containing motivational phrases and meeting reminder. Joint communication was carried out in the study group via the Facebook social network [15].

Researchers from Lebanon have undertaken interventional research to promote healthy eating and physical activity among school-age children. The results of intervention studies ( $n=193$ ) were compared with a control group not included in the health programme $(n=181)$. Children from the intervention group bought and consumed less fries and sugar sweetened beverages, compared to the control group. Knowledge and self-efficacy increased among the study group covered by the programme. Interviews conducted with the focus groups demonstrate that the above programme was generally well received [16]. Researchers from Australia and New Zealand carried out interventions in primary schools to increase the effectiveness of physical activity, and their programme was distinguished by the fact that school teachers also participated through online learning and individualized mentoring. Therefore, the knowledge acquired could be put into practice and passed on to the pupils [17]. Nezami et al. tested the effectiveness of a 6-month programme via smartphones to reduce the consumption of sugar sweetened beverages and juices among children ..... and? [18].

\section{CONCLUSIONS}

The expectations of parents of young school-age children regarding school medical care and healthy school activities are very high. Most of the respondents demonstrate approval for health-related tasks carried out in schools. Some expectations of respondents deviated from the principles of healthy lifestyle, including the desire for a sweet dessert to be served with the meal.

The study demonstrates the existence of a relationship between parents' expectations of health promoting activities in the teaching and upbringing environment, and health behaviours in the child's family. Higher HBI scores indicate higher expectations for health evaluations, vaccinations in cooperation with a paediatrician, counselling for the school head, active counselling in the field of nursing care, as well as performing visual acuity tests and anti-lice prophylaxis.

\section{REFERENCES}

1. Bogusz R, Charzyńska-Gula M, Grzesiak A, Gałęziowska E. Współpraca pielęgniarek szkolnych $\mathrm{z}$ nauczycielami wychowania fizycznego w zakresie promocji zdrowia i edukacji zdrowotnej. Med Og Nauk Zdr. 2013; 19(4): 413.

2.Leńczuk-Gruba A, Kobos E. Współpraca w zakresie edukacji zdrowotnej z dyrekcją i nauczycielami szkoły w opinii pielęgniarki środowiska nauczania i wychowania. Pielęg Pol. 2007; 4(26): 265.

3. Widomska-Czekajska T, Górajek-Jóźwik J (red.). Encyklopedia dla pielęgniarek i położnych. Tom 2. Wyd. I. PZWL, Warszawa, 2010; 744.

4. Charzyńska-Gula M, Jaworska M, Bogusz R, Bartoszek A, Kocka K. Rodzina i szkoła jako źródła informacji zdrowotnej - opinie uczniów. Med Og Nauk Zdr. 2013; 19(3): 242.

5. Bednarek A, Bednarz M. Zachowania zdrowotne chłopców i dziewcząt w młodszym wieku szkolnym. Med Og Nauk Zdr. 2013; 19(3): 305-310.

6. Wojciechowska K. Nauczyciel - przewodnikiem w procesie promowania zdrowia w szkole. Rocz Pedag. 2014; 6(2): 127-130.

7. Juczyński Z. Narzędzia pomiaru w promocji i psychologii zdrowia. Pracownia Testów Psychologicznych Polskiego Towarzystwa Psychologicznego. Warszawa, 2001; 121.

8. Cag D, Mucha P, Janiszewska-Olszowska J. Świadomość rodziców dzieci klas I w zakresie profilaktyki stomatologicznej i ortodontycznej. Stomatol Współcz. 2008; 15(5): 16.

9. Charzyńska-Gula M, Jaworska M, Bogusz R, Kocka K, DomżałDrzewicka R, Wasil A. Realizacja edukacji zdrowotnej w szkole podstawowej, gimnazjum i liceum w świetle opinii wybranej grupy uczniów. Med Og Nauk Zdr. 2013; 19(4): 431, 433.

10. Foster BA, Aquino Ch, Flores G, Hale D. A Randomized Clinical Trial of the Effects of Parent Mentors on Early Childhood Obesity: Study Design and Baseline Data. HHS Public Access, Contemp Clin Trials, 2015 November; 45: 164-169. http://dx.doi.org/10.1016/j.cct.2015.08.017

11. Grzywacz R. Rola rekreacji ruchowej w wychowaniu dzieci w wieku szkolnym. Med Rodz. 2011; 2: 49, 50-51.

12. Pachla B. Oczekiwania, dylematy i kompetencje: Jak zmieniły się obowiązki higienistki i pielęgniarki szkolnej? Mag Pielęg Położ. 2015; 01-02: 8 .

13. Kardas M, Nowak J, Kiciak A, Grochowska-Niedworok E. Promocja zdrowa w aspekcie asortymentu produktów oferowanych przez sklepiki szkolne. Med Og Nauk Zdr. 2013; 19(4): 421-422.

14. Wolnicka K, Jaczewska-Schuetz J. Organization of nutrition and health promotion activities in the field of nutrition and physical activity in primary schools. Zdr Publ. 2012; 122(4): 343.

15. Minossi V, Pellanda LC. The „Happy Heart” educational program for changes in health habits in children and their families: protocol for a randomized clinical trial. BMC Pediatrics, 2015, 15: 19. DOI 10.1186/ s12887-015-0336-5, https://doi.org/10.1186/s12887-015-0336-5

16. Habib-Mourad C, Ghandour LA, Moore HJ, Nabhani-Zeidan M, Adetayo K, Hwalla N I wsp. Promoting healthy eating and physical activity among school children: fundings from Health-E-PALS, the first pilot intervention from Lebanon. BMC Public Health, 2014, 14: 940. http://www.biomedcentral.com/1471-2458/14/940

17. Lonsdale Ch, Sanders T, Cohen KE, Parker P, Noetel M, Hartwig T, et al. Scaling-up an efficacious scholl-based physical activity intervention: Study protocol for the 'Internet-based Professional Learning to help teachers suport Activity in Youth' (iPlay) cluster randomized controlless trial and scale-up implementation evaluation. BMC Public Health 2016, 16: 873. DOI 10.1186/s12889-016-3243-2, http://hdl.handle.net/10536/ DRO/DU:30085779

18. Nezami BT, Lytle LA, Tate DF. A randomized trial to reduce sugarsweetened beverage and juice intake in preschool-aged children: description of the Smart Moms intervention trial. BMC Public Health, 2016, 16: 837. DOI 10.1186/s12889-016-3533-8, https://doi.org/10.1186/ s12889-016-3533-8 